\section{Morphology, Growth, and Rhizome Development of Vaccinium angustifolium Ait. Seedlings, Rooted Softwood Cuttings, and Micropropagated Plantlets}

\author{
Sharon Morrison', John M. Smagula ${ }^{2}$, and Walter Litten ${ }^{3}$ \\ Department of Biosystems Science and Engineering, University of Maine, \\ Orono, ME 04469-5722
}

Additional index words. lowbush blueberry, tissue culture, propagation

\begin{abstract}
For accelerating the filling in of bare areas in native lowbush blueberry fields or converting new areas to production, micropropagated plantlets rooted after three subcultures outperformed seedlings and rooted softwood cuttings. After 2 years of field growth, they averaged 20.3 rhizomes each of average dry weight $3.5 \mathrm{~g}$, as compared with 5.7 rhizomes of average dry weight $1.1 \mathrm{~g}$ for rooted softwood cuttings. After 1 year of field growth, seedlings produced on average $3.3 \mathrm{vs.} 0.4$ rhizomes from micropropagated plants that had not been subcultured and 0.3 rhizomes from stem cuttings. Apparently, subculturing on cytokinin-rich media induces the juvenile branching characteristic that provides micropropagated plants with the desirable morphologies and growth habits of seedlings. These characteristics favor rhizome production while the benefits of asexual reproduction are retained. The advantage in rhizome production of micropropagation over stem cuttings varied among clones.
\end{abstract}

The lowbush blueberry, native to North America, is a commercially important crop in Maine and eastern Canada. As a regional crop subject to year-to-year differences in weather patterns over its region, its variation in yearly production is a disadvantage in the processedfruit marketplace. Production in Maine ranged from 12,000 t in 1989 to 39,000 t in 1992 (New England Agricultural Statistics Service, 1997). The crop's market position in the intensifying competition from species of blueberries cultivated continent-wide has been enhanced by promotion as wild blueberries, bringing to mind charming images from a highly successful children's book where a mother and young daughter compete for blueberries against a mother bear and cub (McCloskey, 1976).

Lowbush blueberry remains largely a wild crop projected by Moore (1994) to be grown in 2000 on twice the area devoted to cultivated blueberries in North America. It has also become an intensively managed wild crop (Smagula and Yarborough, 1990), although yields of lowbush plants are lower than those of its cultivated competitors (Moore, 1994).

Received for publication 22 Mar. 1999. Accepted for publication 2 Sept. 1999. Maine Agricultural and Forest Experiment Station Contribution No. 2356. We gratefully acknowledge the technical assistance of Edward McLaughlin. The cost of publishing this paper was defrayed in part by the payment of page charges. Under postal regulations, this paper therefore must be hereby marked advertisement solely to indicate this fact.

${ }^{1}$ Former Graduate Research Assistant.

${ }^{2}$ Professor of Horticulture; to whom reprint requests should be addressed (smagula@maine.edu).

${ }^{3}$ Faculty Associate.
Incomplete coverage by the two lowbush blueberry species (Vaccinium angustifolium Ait. and V. myrtilloides Michx.) is typical. In young fields Metzger and Ismail (1977) estimated effective coverage by crop at $20 \%$ to $40 \%$. Bare ground may result from inadvertent kills of blueberry plants in applying herbicide, from erosion that had been prevented by weeds, and from "scalping" by machinery. Furthermore, even with full coverage by wild blueberry plants, their genetic variation for traits affecting yield (berry size, number of berries per cluster, stem density) results in more and less fruitful areas in a field. Few growers of lowbush blueberries, however, have been willing to sacrifice some years of income by replacing their wild plants. Kender (1967) recommended row culture, as in strawberries, for higher productivity from such fields. On the basis of faster plant spread he found seedlings better than softwood cuttings for establishing matted rows, and that most cut rhizomes died when planted directly.

Hall (1983) compared berry yields from plants grown from seedlings produced by three types of crosses: 1) uncontrolled from average wild stands, 2) both parents from high-yielding clones, 3) open-pollination of flowers on high-yielding clones, with other high-yielding clones nearby. He was able to rank the three types distinctly by fruit yield, at least for the early crop years of a field's history. Both on the basis of the weight of 25 berries and of harvest yield per unit area of plant coverage, the progeny of two high-yielding clones ranked highest, that of average fields ranked lowest, and that from open-pollinated flowers of highyielding plants were intermediate.

In addition to seedlings and softwood cuttings, micropropagation can be used to propa- gate desirable new clones. Cloning by micropropagation is a more demanding and potentially more effective method for improving lowbush blueberry fields, comparable in its requirements with growing and setting out seedlings.

Anderson (1975) brought tissue culture technology to the Ericaceae in propagating Rhododendron. Zimmerman and Broome (1980) modified Anderson's Rhododendron medium to propagate the highbush blueberry, V. corymbosum L., and Lyrene (1981) propagated rabbiteye blueberry, $V$. ashei Reade, with fast-rooting, seedling-like cuttings from cultures of shoot tissue. Frett and Smagula (1983) used single-bud explants of mature tissue of lowbush blueberry to obtain multiple shoots that subsequently rooted. The juvenile characteristics of tissue-cultured lowbush blueberry plantlets may facilitate rhizome production for quick spread into bare areas of a field. This study compared outplanted tissue-cultured $V$. angustifolium with plants from seedlings and plants started from rooted softwood cuttings.

\section{Materials and Methods}

Stock clones or their derivatives through seed or asexual propagation from the breeding program at the Maine Agricultural Experiment Station or the Research Station, Kentville, N.S., were used in three experiments.

Expt. 1. Rooted softwood stem cuttings and rooted microcuttings were compared for differences in morphology, growth, and rhizome production after one season of growth. Potted plants of Clones 7062 and 7915 grown for 3 years under greenhouse conditions provided stems for rooting and tissue from the same plant for micropropagation. In May, terminal softwood cuttings 7 to $10 \mathrm{~cm}$ long with basal leaves removed were rooted in a limed lowbush blueberry potting medium of 4 screened peat : 2 vermiculite : 1 perlite (by volume) with fritted trace elements in the greenhouse under intermittent mist at $22{ }^{\circ} \mathrm{C}$. Rooted cuttings in $10-\mathrm{cm}$ pots of the medium were grown at 16-h daylength under General Electric F40CW lamps $\left[\approx 25 \mu \mathrm{mol} \cdot \mathrm{m}^{-2} \cdot \mathrm{s}^{-1}\right.$ photosynthetic photon flux $(P P F)]$. In December, dormancy requirements were met in a dark cooler at $3{ }^{\circ} \mathrm{C}$. After 6 weeks the plants were returned to the greenhouse for 1 year. After a second 6-week dormancy period, the plants were returned to the greenhouse until outplanting in May.

Micropropagated plants for comparison with the plants from rooted stems were started at the same time from Clones 7062 and 7915. Shoots from a new flush of growth were stripped of leaves and surface-sterilized in $0.5 \%$ sodium hypochlorite solution from a commercial bleach for $20 \mathrm{~min}$, followed by three rinses in sterile water. Shoots were cut into single-bud explants and placed on medium described by Zimmerman and Broome (1980) using $10 \mathrm{~g} \cdot \mathrm{L}^{-1}$ Phytagar (Gibco, Grand Island, N.Y.) and modified by reducing the concentration of indoleacetic acid (IAA) to 1 $\mathrm{mg} \cdot \mathrm{L}^{-1}$. Shoots produced in vitro in 6 weeks at 
$25^{\circ} \mathrm{C}$ under 16-h daylength at $30 \mu \mathrm{mol} \cdot \mathrm{m}^{-2} \cdot \mathrm{s}^{-1}$ $P P F$ from $60-\mathrm{W}$ fluorescent lamps (General Electric F96T12) were cut into single bud explants and placed on fresh medium. Three subcultures were performed before 3- to 5$\mathrm{cm}$-long shoots were cut and rooted in $10 \times 15$ $\times 5$-cm plastic flats containing the previously described lowbush blueberry potting medium. The flats were then placed in plastic bags and set in the greenhouse under a frame covered with one layer of plastic and three layers of cheesecloth, creating a shaded, high-humidity growth chamber. One layer of cheesecloth was removed each week to acclimate the cuttings slowly to greenhouse light. Tissue-culture plants were grown under the same greenhouse conditions as the rooted cuttings and also received the same dormancy-breaking treatment.

In May, 16 micropropagated plants and 16 plants from softwood cuttings were set out 60 $\mathrm{cm}$ apart in a Colton series soil at Blueberry Hill Farm of the Univ. of Maine, Jonesboro, in 16 randomized complete blocks. Because the clones produced plants that differed considerably in size, plants of Clone 7062 were planted $5 \mathrm{~cm}$ deeper, and the Clone 7915 plants $2.5 \mathrm{~cm}$ deeper, than in the pots. The soil level for outplanting was determined while the plants were in pots. Before planting, vegetative buds above and below this point were counted, as well as the numbers of stems, flower buds, and primary, secondary, and tertiary branches to be left above ground on each plant. Stems were considered to be any portion of a plant that emerged from the soil in the pot. The plots were mulched with $7.5 \mathrm{~cm}$ of sawdust. After 4 months of growth, near the end of the growing season, the entire plants were harvested, the number of rhizomes on each and their lengths measured, and weights of the rhizomes and stems recorded after drying for $2 \mathrm{~d}$ at $61{ }^{\circ} \mathrm{C}$.

Expt. 2. Micropropagated plants and rooted softwood cuttings were compared over 2 years of field growth. At the same time that the plants of Expt. 1 were set out in their test plots, 50 plants grown from Clone 7062 rooted softwood cuttings and 50 micropropagated plants from Clone 7062 as described for Expt. 1 were planted out $60 \mathrm{~cm}$ apart and $5 \mathrm{~cm}$ deeper than in the pots, in the same soil type at Blueberry Hill Farm in a randomized complete-block design in five blocks of like-size plants. Each block consisted of a row of 10 micropropagated plants and 10 plants grown from rooted softwood cuttings, mulched with $7.5 \mathrm{~cm}$ of sawdust.

In May of the second growing season, flower buds were counted on each plant, and in August the berries produced by each plant were weighed. In September, photographs were taken to measure plant spread, and the number of flower buds per plant formed during the second season of growth was assessed.

To measure area covered by a pair of plants encompassed within a $1-\mathrm{m}^{2}$ quadrat, we photographed them from directly above by a camera mounted on the quadrat. The resulting slides were projected onto graph paper ruled into $2.5-\mathrm{cm}$ squares so that the quadrat just filled 400 of the squares. A $2.5-\mathrm{cm}$ square that was less than half-occupied by leaf image was marked by a slash, and a square more than half-filled with leaf image was marked with a circle. Adding the squares with a circle, considered as full coverage, and half the number of squares with a slash, considered half coverage, gave an estimate of area covered by the two plants.

A randomly chosen half of each of the Expt. 2 blocks was dug out at the end of the second growing year, their rhizomes counted and measured, and their tops dried for $2 \mathrm{~d}$ at 61 ${ }^{\circ} \mathrm{C}$ and weighed.

Expt. 3. Propagation from seedlings, the means by which the various clones in blueberry fields originated naturally, was compared with micropropagation and propagation by rooted softwood cuttings. The seedlings were the progeny of crosses of known highyield clones: 1Ells x Ca315, 8Ells x Ca206, $2827 \times 8$ Ells, Ca510 x 2827, and $7062 \times$ Ca510. Plants grown from seed were compared with plants cloned by tissue culture and plants cloned by rooted softwood cuttings from the maternal parent clones 1Ells, 8Ells, 2827, Ca510, and 7062.

The crosses were made in May on potted stock plants of the clones. Flowers removed from a pollen donor plant were rolled between thumb and forefinger and the pollen collected in a petri dish with a red-painted bottom. With artist's paintbrush, pollen was transferred to stigmata protruding on a flower of the receiving clone. Ripe berries from the cross were harvested and the seeds squeezed out on filter paper, surface-sterilized with $0.5 \%$ sodium hypochlorite from a commercial bleach, and then rinsed $3 \times$ with sterile distilled water. Seedlings for the comparison were provided by germinating seeds in petri dishes of water agar at $25^{\circ} \mathrm{C}$ and $16-\mathrm{h}$ photoperiod provided by General Electric F96T12 60-W fluorescent lamps at a level of $30 \mu \mathrm{mol} \cdot \mathrm{m}^{-2} \cdot \mathrm{s}^{-1} P P F$, measured with an Apogee Basic Quantum Meter, model BQM-SUM (Apogee Instruments, Logan, Utah).

Procedure for producing the tissue-cultured plants was as described for Expt. 1, except that no subculturing was done. Shoots 3 to $5 \mathrm{~cm}$ long that had proliferated 6 weeks after culturing were cut and stuck into the potting medium described above in $10 \times 15 \times$ $5-\mathrm{cm}$ plastic flats and acclimated at high humidity to greenhouse conditions as previously described. At the same time in May, softwood cuttings 7 to $10 \mathrm{~cm}$ long were taken from new growth of potted plants of each clone and prepared as previously described for rooting in $32 \times 38 \times 6-\mathrm{cm}$ flats of the same potting medium. In August the rooted softwood cuttings, the rooted tissue-cultured shoots, and seedlings with true leaves were all transplanted into Rootrainers (Spencer-Lemaire Industries Ltd., Edmonton, Alta., Canada) containing the potting medium.

In the Rootrainers randomized in the greenhouse, the plants grew at a minimum temperature of $22^{\circ} \mathrm{C}$ and 16 -h daylength under General Electric F40CW 35-W fluorescent lamps, $\approx 25 \mu \mathrm{mol} \cdot \mathrm{m}^{-2} \cdot \mathrm{s}^{-1} P P F$. After 2 weeks they received a solution containing $50 \mathrm{mg} \cdot \mathrm{L}^{-1} \mathrm{~N}$ from Peters Azalea Neutral Fertilizer 21N-
2.9P-5.8K (Peters Fertilizer Products, Allentown, Pa.). In subsequent weeks, the fertilizer solution was applied with $\mathrm{N}$ concentration raised in $50 \mathrm{mg} \cdot \mathrm{L}^{-1}$ increments to $200 \mathrm{mg} \cdot \mathrm{L}^{-1}$. Fertilization was stopped after 4-1/2 months of the $200 \mathrm{mg} \cdot \mathrm{L}^{-1} \mathrm{~N}$ regime. At 5 months the supplementary lights were turned off, and at 5$1 / 2$ months the greenhouse temperature was reduced to $13{ }^{\circ} \mathrm{C}$ to allow the plants to harden off. At the end of the sixth month, growth characteristics of the plants were measured.

On one randomly selected stem of each plant, leaf area and the lengths of the first four internodes were measured beginning with the first node $>1 \mathrm{~cm}$ below the growing tip (node 1). Leaf area was measured by passing the leaves through a LI-COR portable area meter (model LI-3000; LI-COR, Lincoln, Nebr.). For each plant we recorded the total number of vegetative buds and the number of vegetative buds that would be buried in planting to $5-\mathrm{cm}$ depth, the number of flower buds, the number of stems, and the number of primary, secondary, and tertiary branches. All plants were then cooled at $3{ }^{\circ} \mathrm{C}$ to satisfy the dormancy requirement. In May they were outplanted to the Colton-series soil at Blueberry Hill Farm in randomized complete-block design. To utilize all available plant material, Clones 7062, 2827, Ca510, 8Ells, and 1Ells were replicated in 12 blocks with 15 plants per block; Clones 7062 , 2827, Ca510, and 8Ells in 16 blocks with 12 plants per block; and Clones 7062, 2827, and Ca510 in 20 blocks with nine plants per block. Thus, a block consisted of either five sets of three plants, four sets of three plants, or three sets of three plants, and a set comprised a plant micropropagated from a specific clone, a plant propagated from a softwood cutting of that clone, and a plant propagated from a seedling of which the clone was the maternal parent.

After 4 months of field growth all plants were harvested without leaves, and the rhizomes and aerial portions dried separately in paper bags at $61^{\circ} \mathrm{C}$ for $2 \mathrm{~d}$, and weighed.

Data were subjected to analysis of variance using the General Linear Model of SAS (Release 5.0, SAS Institute, Cary, N.C.). Treatment effects were separated by WallerDuncan's multiple range test at the $1 \%$ level.

\section{Results}

Expt. 1. After 1 year of growth in the field, micropropagated plants of two lowbush blueberry clones exhibited more vigorous rhizome growth than plants obtained by rooted softwood cuttings (Table 1). Compared with the more upright growth of plants from cuttings, the micropropagated plants produced more primary branches on more stems. Micropropagated plants averaged some 4.5 times as many vegetative buds available for burial, and all of these plants produced rhizomes in the field. Only four of the 16 Clone 7062 plants from cuttings produced rhizomes, while eight of the 11 Clone 7915 plants from cuttings that survived a year in the field did so. Micropropagated plants produced longer rhizomes. At outplanting, the cutting-propagated plants had 
Propagation \& Tissue Culture

Table 1. Effect of tissue-culture and stem-cutting propagation on characteristics of two clones of lowbush blueberry before and after one-season's field growth.

\begin{tabular}{|c|c|c|c|c|c|c|}
\hline \multirow[b]{2}{*}{ Characteristic } & \multicolumn{3}{|c|}{ Clone 7062} & \multicolumn{3}{|c|}{ Clone 7915} \\
\hline & Micropropagation & Stem cuttings & Significance & Micropropagation & Stem cuttings & Significance \\
\hline & \multicolumn{6}{|c|}{ Before outplanting } \\
\hline Number of stems & $9.7^{z}$ & 2.1 & $* *$ & 6.8 & 1.6 & $* *$ \\
\hline Primary & 21.6 & 9.1 & ** & 22.9 & 6.9 & $* *$ \\
\hline Secondary & 8.8 & 9.9 & NS & 18.2 & 11.7 & NS \\
\hline Tertiary & 1.2 & 2.8 & $*$ & 4.9 & 4.0 & NS \\
\hline Number of vegetative buds buried & 175.5 & 47.3 & $* *$ & 68.6 & 5.9 & $* *$ \\
\hline & \multicolumn{6}{|c|}{ After one season of field growth } \\
\hline Number of rhizomes & 7.0 & 0.6 & $* *$ & 4.8 & 1.8 & * \\
\hline Rhizome length (mm) & 69.0 & 8.8 & ** & 46.5 & 34.9 & $* *$ \\
\hline Rhizome dry weight (g) & 0.2 & 0.1 & NS & 0.2 & 0.1 & NS \\
\hline Stem dry weight (g) & 4.0 & 2.7 & NS & 4.0 & 2.7 & NS \\
\hline
\end{tabular}

${ }^{2}$ Each value is the average for 16 plants.

Ns, *,** Nonsignificant or significant at $P=0.05$ or 0.01 , respectively.

more flower buds than did the micropropagated plants.

Expt. 2. In the second year of field growth, the micropropagated Clone 7062 plants and the cutting-propagated plants had similar numbers of flower buds, and similar berry weight per plant (Table 2). However, at the end of the second year of field growth, micropropagated plants had $37 \%$ more flower buds than did cutting-propagated plants. All micropropagated plants and 46 of the 50 cutting-propagated plants that survived produced rhizomes, but the micropropagated plants produced almost four times as many. These were longer and had a greater dry weight than those on plants from cuttings. Both propagation methods gave about the same final stem weights and leaf area per plant.

Expt. 3. Before outplanting, micropropagated and cutting-propagated plants had the same stem numbers per plant, but both had more than did seedlings (Table 3 ). After growth in the greenhouse for 6 months, seedlings had developed the least leaf area, cutting-propagated plants the most, and micropropagated plants were intermediate. Micropropagated plants and seedlings had shorter internodes than did rooted cuttings. No flower buds formed on seedling plants and very few on the micropropagated plants. The seedlings had the most vegetative buds and branches on their relatively few stems. With more vegetative buds for burial, this method gave the most rhizomes after a season of field growth. Length and dry weight of the rhizomes produced during field growth, however, were roughly the same for the three methods. Dry weight of stems per plant for the micropropagated plants was about half that for the other methods.

\section{Discussion}

Restoring nonproducing areas of a field or creating a new production area with plants propagated asexually is appealing because of the assurance of high production with known genetic stock (Hall et al., 1978). When they compared yields of eight clonal lines and four seed-propagated lines of the lowbush blueberry, the top six performers were rooted cuttings. One problem associated with rooted

Table 2. Effects of tissue-culture and stem-cutting propagation on characteristics before and after a second season's field growth of lowbush blueberry clone 7062 .

\begin{tabular}{lccc}
\hline \hline Characteristic & Micropropagation & Stem cuttings & Significance \\
\hline Number of flower buds (May) & $51.4^{z}$ & $65.4^{y}$ & NS \\
Berry fresh weight $(\mathrm{g})$ & 43.2 & 37.2 & NS \\
Number of flower buds (September) & 183.2 & 133.9 & $* *$ \\
Number of rhizomes & 20.3 & 5.7 & $* *$ \\
Rhizome length (mm) & 11.9 & 9.6 & $*$ \\
Rhizome dry weight $(\mathrm{g})$ & 3.5 & 1.1 & $* *$ \\
Stem dry weight $(\mathrm{g})$ & 23.1 & 21.1 & Ns \\
Area covered $\left(\mathrm{cm}^{2}\right)$ & 739.6 & 692.0 & Ns
\end{tabular}

${ }^{2}$ Each value is the average for 50 micropropagated plants.

'Each value is the average for 46 plants propagated from stem cuttings.

Ns, ${ }^{*},{ }^{* *}$ Nonsignificant or significant at $P=0.05$ or 0.01 , respectively.

Table 3. Effects of propagation by seed, micropropagation (without subculture), or stem cuttings on characteristics of five lowbush blueberry clones (clones 7062, 2827, Ca510, 8Ells, and 1Ells ${ }^{2}$ ) before and after one season of field growth.

\begin{tabular}{|c|c|c|c|}
\hline Characteristic & Seed $^{y}$ & Micropropagation & Stem cuttings \\
\hline & \multicolumn{3}{|c|}{ Before outplanting } \\
\hline Number of stems & $1.2 \mathrm{a}^{\mathrm{x}}$ & $1.5 \mathrm{~b}$ & $1.5 \mathrm{~b}$ \\
\hline \multicolumn{4}{|l|}{ Number of branches } \\
\hline Primary & $5.2 \mathrm{a}$ & $2.3 \mathrm{~b}$ & $2.6 \mathrm{~b}$ \\
\hline Secondary & $2.4 \mathrm{a}$ & $0.7 \mathrm{~b}$ & $0.6 \mathrm{~b}$ \\
\hline Tertiary & $0.2 \mathrm{a}$ & $0.0 \mathrm{~b}$ & $0.0 \mathrm{~b}$ \\
\hline Internode length (mm) & $5.4 \mathrm{a}$ & $6.1 \mathrm{a}$ & $8.3 \mathrm{~b}$ \\
\hline Leaf area $\left(\mathrm{cm}^{2}\right)$ & $5.3 \mathrm{a}$ & $7.5 \mathrm{~b}$ & $12.5 \mathrm{c}$ \\
\hline Number of flower buds & $0.0 \mathrm{a}$ & $0.9 \mathrm{a}$ & $4.7 \mathrm{~b}$ \\
\hline Number of vegetative buds & $137.3 \mathrm{a}$ & $47.8 \mathrm{~b}$ & $50.3 \mathrm{~b}$ \\
\hline Number of vegetative buds buried & $44.1 \mathrm{a}$ & $18.7 \mathrm{~b}$ & $10.8 \mathrm{c}$ \\
\hline \multicolumn{4}{|c|}{ After one season of field growth } \\
\hline Number of rhizomes & $3.3 \mathrm{a}$ & $0.4 \mathrm{~b}$ & $0.3 \mathrm{~b}$ \\
\hline Rhizome length (mm) & $6.1 \mathrm{a}$ & $4.3 \mathrm{a}$ & $5.3 \mathrm{a}$ \\
\hline Rhizome dry weight (g) & $0.2 \mathrm{a}$ & $0.2 \mathrm{a}$ & $0.1 \mathrm{a}$ \\
\hline Stem dry weight (g) & $1.68 \mathrm{a}$ & $0.8 \mathrm{~b}$ & $1.5 \mathrm{a}$ \\
\hline
\end{tabular}

${ }^{2}$ Clone 7062, $\mathrm{n}=144$; clone 2827, $\mathrm{n}=144$; clone Ca510, $\mathrm{n}=144$; clone 8Ells, $\mathrm{n}=84$; and clone 1Ells, $\mathrm{n}=36$. 'Each value is the average for 186 plants.

${ }^{x}$ Mean separation within rows by Waller-Duncan multiple range test, $P \leq 0.01$.

cuttings is an inconsistency in production of rhizomes. While larger and more vigorous rooted cuttings produce more rhizomes, clones reacted differently to $\mathrm{N}$ fertilizer treatments aimed at stimulating rhizomes (Smagula and Hepler, 1980). Aalders and Hall (1968) found that planting with one-third to one-half of the top underground increased survival and spread, possibly because buried branches prevent heaving by the formation of adventitious roots and because buried buds may develop into rhizomes.
Micropropagated lowbush blueberry plants from shoots that passed through several subcultures had smaller leaves and shorter internodes similar to those of seedlings, as reported for Vaccinium ashei cultivars (Lyrene, 1981). Juvenility is also evident in the branching characteristics and scant flower bud formation of clones 7062 and 7915 (Table 1). The short duration of this juvenility is evident from the number of flower buds formed by the micropropagated plants after 1 and 2 years of field 
growth (Table 2, May and September data). Micropropagated plants that did not result from subcultures (Table 3) had stem characteristics more similar to stem cuttings than to seedlings, with less branching than seedlings and fewer vegetative buds for burying. These plants produced no more rhizomes than did stem cuttings. Subculturing on cytokinin-rich media apparently induces the juvenile branching characteristic that provides micropropagated plants with the desirable morphological and growth habits of seedlings with the benefits associated with asexual propagation.

Growers must decide if the higher cost of the micropropagated plants is justified by longterm increase in fruit yields of clonal material. While crosses of known high-yield clones will serve well for increasing plant cover in commercial lowbush blueberry fields, it is less certain that they will yield as well in commercial lowbush blueberry fields.

\section{Literature Cited}

Aalders, L.E. and I.V. Hall. 1968. The effect of depth of planting on the survival, yield, and spread of the common lowbush blueberry Vaccinium angustifolium Ait. HortScience 3:72-74.

Anderson, W.C. 1975. Propagation of rhododendrons by tissue culture: Part 1: Development of a culture medium for multiplication of shoots. Proc. Intl. Plant Prop. Soc. 25:129-135.

Frett, J.J. and J.M. Smagula. 1983. In vitro shoot production of lowbush blueberry. Can. J. Plant Sci. 63:467-472.

Hall, I.V. 1983. Genetic improvement of the lowbush blueberry, Vacciniumangustifolium. Can. J.Plant Sci. 63:1091-1092.

Hall, I.V., L.E. Aalders, and D.L. Craig. 1978. Propagation of lowbush blueberries. Agr. Can. Publ.

Kender, W.J. 1967. On the domestication of the lowbush blueberry. Fruit Var. Hort. Dig. 21:74-76.

Lyrene, P.M. 1981. Juvenility and production of fast-rooting cuttings from blueberry shoot cultures. J. Amer. Soc. Hort. Sci. 106:396-398.
McCloskey, R. 1976. Blueberries for Sal. Puffin Books, N.Y.

Metzger, H.B. and A.A. Ismail. 1977. Costs and returns in lowbush blueberry production in Maine, 1974 Crop. Univ. of Maine Life Sci. and Agr. Expt. Sta. Bul. 738.

Moore, J.N. 1994. The blueberry industry of North America. HortScience 4:96-102.

New England Agricultural Statistics Service. 1997. Maine wild blueberries. New England Agr. Stat. Serv., Concord, N.H. 24 July 1997.

Smagula, J.M. and P.R. Hepler. 1980. Effect of nitrogen status of dormant rooted lowbush blueberry cuttings on rhizome production. J. Amer. Soc. Hort. Sci. 105:283-285.

Smagula, J.M. and D. Yarborough. 1990. Changes in the lowbush blueberry industry. Fruit Var. J. 44:72-76.

Zimmerman, R.H. and O.C. Broome. 1980. Blueberry micropropagation. Proc. Conf. on Nursery Prod. of Plants Through Tissue Cult.-Applications and feasibility. Beltsville, Md. U.S. Dept. Agr. Publ. ARE-NE-11. 